\title{
Generic substitution of antiepileptic drugs: What's a clinician to do?
}

Nitin K. Sethi, MD, New York-Presbyterian Hospital: I read with interest the commentary by Dr. Privitera ${ }^{1}$ on generic substitution of antiepileptic drugs (AEDs). As an epileptologist, I am used to routinely having a generic AED substituted for a brand-name product. I have come to the sad realization that it is easy to write a script for a brand-name AED, but getting it for the patient is a far more arduous task. My first hurdle is the patient's insurance carrier. If my patient and I are lucky, the brand-name AED is covered by the insurance carrier. Still, I have to get prior approval for the medication first: Was the generic version of the AED tried? If yes, did the patient fail the generic version of the AED or have side effects? Good luck getting the brand name AED if the answers to those questions are no. Assuming we clear these hurdles, it is still too early to pat oneself on the back. I may get a call from the pharmacist or the patient informing me that the out-of-pocket cost for the brand-name AED is $\$ 150$ for 120 pills. The patient wants to know if it is okay to take the generic AED so that he or she does not have to bear this monthly expenditure. I sigh and approve the generic substitution. While generic substitution of AED for a patient whose seizures are well-controlled on brand-name medication intuitively makes little sense, obtaining a brand-name AED for a newly diagnosed patient with epilepsy is now virtually impossible. There is indeed a pressing need for additional studies to determine whether there is bioequivalence and therapeutic equivalence between brand and approved generic AEDs currently available on the market.

Disclosures: N. Sethi serves as Associate Editor for The Eastern Journal of Medicine.

Correspondence to: sethinitinmd@hotmail.com

1. Privitera M. Generic substitution of antiepileptic drugs: what's a clinician to do? Neurol Clin Pract 2013;3:161-164.

Author Responds: Michael Privitera, MD, University of Cincinnati Neuroscience Institute: I thank Dr. Sethi for his comments on the practical aspects of generic substitution for the clinician and patient. I agree that the hurdles provided by insurance carriers when trying to get the product that we as clinicians believe is equivalent are often difficult and sometimes impossible to overcome. Insurance carriers are allowed to do this because the Food and Drug Administration (FDA) has deemed the products as equivalent with no need for further testing. The hypothesis we are testing in our ongoing study is whether the methods used by the FDA are sufficient to establish bioequivalence for all patients. The other important point that Dr. Sethi makes is the concept that patients need to "fail" a trial of generic substitution to qualify for a brand-name prescription. Failure of generic substitution for a heartburn medication has a much different impact on quality of life than failure of a generic AED in a patient who has been seizure-free for 4 or 5 years and who is now driving and working. It is unethical for an insurance carrier to require failure on drugs like antiepileptics, immunosuppressants for organ transplants, or cancer chemotherapy before covering a brand-name drug for a seriously ill patient. We are eager to provide the results of our generic equivalence trials once completed, but even then, much work will need to be done.

Disclosures: M. Privitera serves on a DSMB for Upsher Smith and as a consultant for Eli Lilly, serves on the editorial board for Annals of Pharmacotherapy, has served on the Speakers' Bureau for UCB and Pfizer, and receives research support from UCB, Eisai, Neuren Pharmaceuticals, the NIH, and the FDA.

Correspondence to: privitmd@ucmail.uc.edu 


\title{
Neurology ${ }^{\circ}$ Clinical Practice
}

\author{
Generic substitution of antiepileptic drugs: What's a clinician to do? \\ Nitin K. Sethi and Michael Privitera \\ Neurol Clin Pract 2013;3;276 \\ DOI 10.1212/CPJ.0b013e3182a2e454
}

This information is current as of August 19, 2013

Updated Information \&
Services
References
Permissions \& Licensing
Reprints

Updated Information \&

Reprints including high resolution figures, can be found at:

http://cp.neurology.org/content/3/4/276.full.html

This article cites 1 articles, 1 of which you can access for free at: http://cp.neurology.org/content/3/4/276.full.html\#\#ref-list-1

Information about reproducing this article in parts (figures,tables) or in its entirety can be found online at:

http://cp.neurology.org/misc/about.xhtml\#permissions

Information about ordering reprints can be found online:

http://cp.neurology.org/misc/addir.xhtml\#reprintsus

Neurol Clin Pract is an official journal of the American Academy of Neurology. Published continuously since 2011, it is now a bimonthly with 6 issues per year. Copyright (C) 2013 American Academy of Neurology. All rights reserved. Print ISSN: 2163-0402. Online ISSN: 2163-0933.

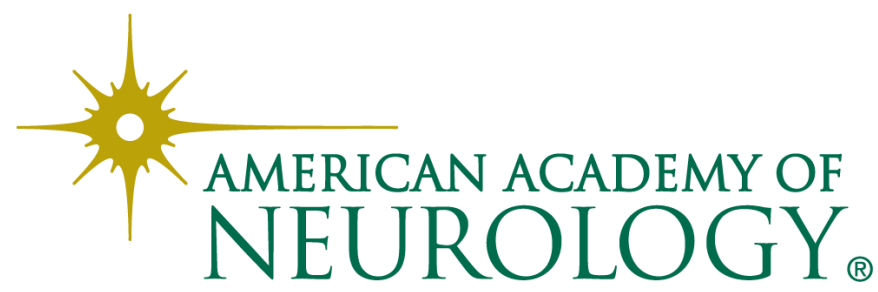

